\title{
Electron paramagnetic resonance and magnetic properties of $\alpha-\mathrm{BiNb}_{1-x} \mathrm{Fe}_{x} \mathrm{O}_{4-\delta}$
}

\author{
N. A. Zhuk ${ }^{1, \dagger}$, L. S. Feltsinger ${ }^{1}$, N. V. Chezhina' ${ }^{2}$, V.P. Lutoev ${ }^{3}$, B. A. Makeev ${ }^{3}$, V. A. Belyy ${ }^{4}$ \\ †nzhuck@mail.ru
}

${ }^{1}$ Syktyvkar State University, 55 Oktyabrskiy ave., Syktyvkar, 167001, Russia

${ }^{2}$ St. Petersburg State University, 26 Universitetskiy ave., St. Petersburg, 198504, Russia

${ }^{3}$ Institute of Geology, Komi Scientific Center, Ural Branch of RAS, 54 Pervomaiskaya str., Syktyvkar, 167982, Russia

${ }^{4}$ Institute of Chemistry, Komi Scientific Center, Ural Branch of the RAS, 48 Pervomaiskaya str., Syktyvkar, 167982, Russia

Iron-containing ceramic materials based on $\mathrm{BiNbO}_{4}$ of orthorhombic modification were obtained by solid-phase synthesis. Solid solutions $\alpha-\mathrm{BiNb}_{1-x} \mathrm{Fe}_{x} \mathrm{O}_{4-\delta}$ were synthesized in the narrow concentration interval of $x \leq 0.03$. The single-phase structure of the samples prepared was determined by X-ray diffraction and SEM- analyses. In the electron paramagnetic resonance (EPR) spectra of $\mathrm{BiNb}_{1-x} \mathrm{Fe}_{x} \mathrm{O}_{4-\delta}$, a wide band with the center at $g=2.16-2.37$ was observed, and a low-intensity signal with $g$-factor of about 4.3 was recorded on its low-field wing. Along with the broad spectrum component, a "noise-like" signal formed by a large number of narrow lines related to the integral signal of ferromagnetic resonance (FMR) and its fine structure was observed in the magnetic field range of 190-400 mT. Based upon measurements of magnetic susceptibility, the paramagnetic components and the effective magnetic moment values of iron atoms at different temperatures and for different concentrations of solid solutions were calculated. The isotherms of the paramagnetic component of the magnetic susceptibility of iron atoms in $\mathrm{BiNb}_{1-x} \mathrm{Fe}_{x} \mathrm{O}_{4-\delta}$ were typical of antiferromagnets. The value of the effective magnetic moment of iron atoms increased with the rise in temperature from $5.84 \mu \mathrm{B}$ at $90 \mathrm{~K}$ to $6.43 \mu \mathrm{B}$ at $320 \mathrm{~K}$. This can be explained by the presence of exchange-bonded aggregates of Fe (III) atoms with antiferromagnetic and ferromagnetic types of exchange in the solid solutions. The magnetic behavior of $\mathrm{BiNb}_{1-x} \mathrm{Fe}_{x} \mathrm{O}_{4-\delta}$ was investigated by theoretical calculation of magnetic susceptibility within the framework of the model of diluted solid solutions taking into account the presence of possible types of clusters of iron atoms. The best agreement between the experimental and calculated data was obtained for the dimer parameters of $J_{\text {dim }}=-17 \mathrm{~cm}^{-1}$ and $J_{\text {dim }}=45 \mathrm{~cm}^{-1}$ for the antiferromagnetic and ferromagnetic types of exchange.

Keywords: magnetic susceptibility, EPR, iron, $\mathrm{BiNbO}_{4}$.

УДК: 541. 122: 538. 214

\section{ЭПР и магнитные свойства $\alpha-\mathrm{BiNb}_{1-x} \mathrm{Fe}_{x} \mathrm{O}_{4-\delta}$}

\author{
Жук Н.А. ${ }^{1 \dagger}$, Фельцингер Л.С. ${ }^{1}$, Чежина Н. В. ${ }^{2}$, Лютоев В. П. ${ }^{3}$, Макеев Б. А. ${ }^{3}$, Белый В. А. ${ }^{4}$ \\ ${ }^{1}$ Сыктывкарский государственный университет, Октябрьский пр-т, 55, Сыктывкар, 167001, Россия \\ ${ }^{2}$ Санкт-Петербургский государственный университет, Университетский пр-т, 26, Санкт-Петербург, 198504, Россия \\ ${ }^{3}$ Институт геологии Коми НЦ УрО РАН, Первомайская ул., 54, Сыктывкар, 167982, Россия \\ ${ }^{4}$ Институт химии Коми НЦ УрО РАН, Первомайская ул., 48, Сыктывкар, 167982, Россия
}

Твердофазным синтезом получены железосодержащие керамические материалы на основе ортониобата висмута орторомбической модификации. Твердые растворы $а$ - $\mathrm{BiNb}_{1-x} \mathrm{Fe}_{x} \mathrm{O}_{4-\delta}$ получены в узком концентрационном интервале $x \leq 0.03$, однофазность полученных препаратов установлена методами рентгенофазового и микрозондового анализов. В спектрах электронного парамагнитного резонанса (ЭПР) твердых растворов зарегистрирована широкая линия с центром $g=2.16-2.37$, на ее низкополевом крыле фиксируется малоинтенсивный сигнал с $g$-фактором $~ 4.3$. На фоне широкого компонента спектра в диапазоне магнитных полей 190-400 мТ наблюдается «шумоподобный» сигнал из большого количества узких линий, отнесенных к интегральному сигналу ферромагнитного резонанса $(Ф \mathrm{MP})$ и его тонкой структуре. На основании измерений магнитной восприимчивости рассчитаны парамагнитные составляющие магнитной восприимчивости и значения эффективных магнитных моментов атомов железа при разных температурах и для различных концентраций твердых растворов. Изотермы парамагнитной составляющей магнитной восприимчивости атомов железа в твердых растворах типичны для антиферромагнетиков. Величина эффективного магнитного момента атомов железа, рассчитанная в результате экстраполяции концентрационных 
зависимостей величин магнитной восприимчивости на бесконечное разбавление твердых растворов возрастает с ростом температуры от 5.84 МБ при 90 К до 6.43 МБ при 320 К, что обусловлено присутствием в твердых растворах обменносвязанных агрегатов из атомов Fe (III) с антиферромагнитным и ферромагнитным типами обмена. С целью описания магнитного поведения твердых растворов орторомбической модификации с учетом наличия возможных кластеров из атомов железа выполнен теоретический расчет магнитной восприимчивости в рамках модели разбавленного твердого раствора и сопоставление полученных значений с экспериментальными. Наилучшее согласие экспериментальных и расчетных данных получено при значениях параметра антиферромагнитного обмена в димерах $J_{\partial и м}=-17 \mathrm{~cm}^{-1}$, ферромагнитного $J_{\text {дим }}=45 \mathrm{~cm}^{-1}$.

Ключевые слова: магнитная восприимчивость, ЭПР, железо, $\mathrm{BiNbO}_{4}$.

\section{Introduction}

Bismuth orthoniobate attracts the researchers' attention due to its catalytic [1] and microwave dielectric properties [2]. Due to the relatively low temperature of synthesis, bismuth orthoniobate and its solid solutions are promising as a dielectric interface in monolithic capacitors and EMC filters for super-high frequency equipment [3]. To optimize the electrophysical properties of bismuth orthoniobate based ceramics, the $\mathrm{BiNbO}_{4}$ composition is widely but inconsistently modified by means of an iso- and heterovalent substitution of niobium and bismuth atoms by the ones of transition elements [4-16], whereas little attention is paid to the chemical structure of the complex oxides. The present paper demonstrates the possibility of synthesizing ironcontaining solid solutions $\mathrm{BiNb}_{1-x} \mathrm{Fe}_{x} \mathrm{O}_{4-\delta}$ of orthorhombic modification and reports the results of the studies on the electron state and nature of the exchange interactions between paramagnetic atoms in the solid solutions by the techniques of magnetic dilution and electron paramagnetic resonance (EPR).

The current study was carried out in order to find out the effects of characteristics of crystal structure of bismuth orthoniobate of orthorhombic modification on the distribution and nature of the exchange interactions between paramagnetic atoms in the solid solutions. In this case, ironcontaining solid solutions are useful model materials for studies for several reasons, one of which is the possibility of the most precise calculations of exchange interactions in the clusters of $\mathrm{Fe}$ (III) paramagnetic atoms in crystal fields of octahedral symmetry (term ${ }^{6} \mathrm{~A}_{1 \mathrm{~g}}$ ) within the frame of the Heisenberg-Dirac-van Vleck model (HDVV model) [17].

As it was mentioned above, the solid solutions of bismuth orthoniobate of the low-temperature orthorhombic modification $\left(\alpha-\mathrm{BiNbO}_{4}\right)$ were studied here. The crystal structure of $\alpha-\mathrm{BiNbO}_{4}$ (Pnna, $a=0.4980 \mathrm{~nm}, b=1.1709 \mathrm{~nm}$, $c=0.5675 \mathrm{~nm}$ ) belongs to the class of pseudo-layered structures. Corrugated layers parallel to the crystal plane (ac) are formed by niobium-oxygen octahedra connected to each other at equatorial vertices. The axial planes of these octahedra are inclined and shifted with respect to each other, and neighboring niobium atoms are bonded via oxygen atoms by bonds making an angle $120^{\circ}$ [18-19]. Bismuth orthoniobate crystallizes in the rhombic crystal system at the temperature of synthesis, which does not exceed $1020^{\circ} \mathrm{C}$. At higher temperatures, a reconstructive phase transition to a triclinic modification $\left(\beta-\mathrm{BiNbO}_{4}\right.$, space group $P-1$, $a=0.771 \mathrm{~nm}, b=0.555 \mathrm{~nm}, c=0.797 \mathrm{~nm}, \alpha=89^{\circ}, \beta=77^{\circ}$, $\gamma=87^{\circ}$ ) occurs.

\section{Experiment}

The samples of bismuth orthoniobate solid solutions of the orthorhombic modification were synthesized by means of a standard ceramic technique using step-by-step burning of bismuth (III), niobium (V) and iron (III) oxides of "puriss. spec." grade at temperatures $650^{\circ} \mathrm{C}, 750^{\circ} \mathrm{C}, 850^{\circ} \mathrm{C}$ and $950^{\circ} \mathrm{C}$ for 50 hours. The phase composition of the specimen under investigation was controlled by scanning electron microscopy (microscope Tescan VEGA 3LMN and energy dispersive spectrometer INCA Energy 450) and X-ray phase analysis (DRON-4-13, $\mathrm{Cu}_{\mathrm{Ka}}$-radiation), the parameters of the lattice cell of solid solutions were calculated using CSD software package [20]. The numerical determination of iron content in the samples of solid solutions was carried out by means of atomic emission spectroscopy (SPECTRO CIROS spectrometer with inductively-coupled plasma).

The measurements of magnetic susceptibility were performed by the Faraday method within the range of temperatures $77 \mathrm{~K}-400 \mathrm{~K}$ at 16 fixed temperature values and magnetic field strength values of 7240 Oe, 6330 Oe, 5230 Oe and 3640 Oe.

The EPR spectra were recorded with an X-band radiospectrometer SE/X 2547 (RadioPAN) in the Shared Services Center "Geonauka" at the Komi Scientific Center of the Ural Branch of the Russian Academy of Sciences. The spectra recording was done with a rectangular resonator (RX102, mode TE 102) at room temperature as a first-order derivative at high-frequency modulation $100 \mathrm{MHz}$ with amplitude $0.25 \mathrm{mT}$ and microwave field strength $35 \mathrm{~mW}$. To calibrate the amplification of the equipment, an EPR signal from a miniature reference sample (anthracite, singlet line with $g_{0}=2.0032, \Delta B p p=0.5 \mathrm{mT}$ ) was used. For each sample the spectrum was recorded within the range of magnetic fields $0-700 \mathrm{mT}$, and the lines of the reference standard with scanning $5 \mathrm{mT}$ were recorded separately. The samples spectra were adjusted to equal values of the reference standard intensity and normalized to the equal test charge.

\section{Results and discussion}

Iron-containing solid solutions $\mathrm{BiNbO}_{4}$ were obtained within the narrow concentration interval at $x \leq 0.03$. The single-phase condition of the specimen obtained was proved by the X-ray phase and microprobe analyses (Fig. S1 a (see supplementary material)). The samples of solid solutions are porous compacts composed of sintered crystal grains of the size below $2-3 \mu \mathrm{m}$ (Fig. S1 b). Using the method of energy dispersive $\mathrm{X}$-ray spectroscopy, it was proved that the 
chemical composition of the samples corresponded to the theoretically preassigned one (Fig. S1 c). The parameters of the lattice cell of the solid solutions are close to those of bismuth orthoniobate: $c=0.5674 \mathrm{~nm}, b=1.1706 \mathrm{~nm}$, $a=0.4978 \mathrm{~nm}(x=0.003)$ and $c=0.5677 \mathrm{~nm}, b=1.1701 \mathrm{~nm}$, $a=0.4978 \mathrm{~nm}(x=0.03)$, that is caused by the narrow concentration interval of existence of solid solutions and isomorphous substitution of niobium $(\mathrm{V})$ atoms by similarsized iron (III) cations in the octahedral site $\left(\mathrm{R}\left(\mathrm{Nb}^{+5}\right)=0.064\right.$; $\left.\mathrm{R}\left(\mathrm{Fe}^{+3}\right)=0.0645 \mathrm{~nm}\right)[21]$.

Basing on the measurements of magnetic susceptability of the solid solutions, the paramagnetic components of magnetic susceptability $\chi^{\text {para }}(\mathrm{Fe})$ and values of effective magnetic moments $\mu_{\text {eff }}(\mathrm{Fe})$ of iron atoms at different temperatures for different concentrations of solid solutions of bismuth orthoniobate were calculated. The isotherms of paramagnetic component of magnetic susceptibility of iron atoms in the solid solutions are typical of antiferromagnets (Fig. 1a).

The effective magnetic moment of iron atoms calculated by an extrapolation of the concentration dependencies of $\chi^{\text {para }}(\mathrm{Fe})$ to an infinite dilution of the solid solutions increases with temperature (Table 1 ) from $5.84 \mu \mathrm{B}$ at $90 \mathrm{~K}$ up to $6.43 \mu \mathrm{B}$ at $320 \mathrm{~K}\left(\alpha-\mathrm{BiNbO}_{4}\right)$.

The temperature dependence and higher values of the magnetic moment of iron atoms as compared to the spin values of $\mathrm{Fe}(\mathrm{III})\left(\mu_{\text {eff }}=5.92 \mu \mathrm{B}\right.$, term $\left.{ }^{6} \mathrm{~A}_{\mathrm{lg}}\right)$ and $\mathrm{Fe}(\mathrm{II})$ $\left(\mu_{\text {eff }}=4.9 \mu \mathrm{B},{ }^{5} \mathrm{~T}_{2 \mathrm{~g}}\right)$ are due to the exchange interactions of antiferromagnetic or ferromagnetic types in the clusters of $\mathrm{Fe}(\mathrm{III})$ atoms. The decrease in magnetic susceptibility of iron atoms with the increase in concentration of solid solutions is associated with the dominance of antiferromagnetic interactions between paramagnetic atoms in the clusters. This assumption is also confirmed by a downshift of temperature dependencies of the effective magnetic moment of paramagnetic atoms with an increase in iron concentration in solid solutions (Fig. 1b).

In the EPR spectra of $\mathrm{BiNb}_{1-x} \mathrm{Fe}_{x} \mathrm{O}_{4-\delta}(0.003 \leq x \leq 0.03)$ samples, a wide line of a Gaussian shape with the center at $g=2.16-2.37$ and width $\triangle B p p=130-160 \mathrm{mT}$ was recorded. In its low-field part, a low intensity signal with $g \sim 4.3$ (Fig. 2a), typical of $\mathrm{Fe}^{3+}$ ions in the crystal field of octahedral symmetry with the maximum orthorhombic distortion $E / D \approx 1 / 3$, is present [22]. The wide component of the spectra originates from iron (III) ions and their clusters in less distorted octahedral cation sites in the structure of bismuth orthoniobate. The appearance of a set of signals with $g \sim 4.3$ and $g \sim 2.2$ in the EPR spectrum suggests an inequivalence of cation sites of iron atoms in the structure of solid solutions.

Along with the broad spectrum component, a "noiselike" signal formed by a large number of narrow lines is observed in the magnetic field range of 190-400 mT. It can easily be separated by subtracting the corresponding smoothed spectrum from the EPR spectra (Fig. 2b,c). The position of the narrow lines changes when tilting the testtube even at a slight angle, and repeated recording of the spectrum without changing the test-tube position reproduces the lines completely that indicates their "non-noise" nature. The noise intensity, as is seen in Fig. 2b, is much lower than the absorption signal. According to [22], narrow "noise-like" anisotropic lines on the background of the broad spectrum component can be related to the integral signal of FMR and its fine structure emerging due to magnetization jumps of finely dispersed ferromagnetic particles. The coexistence of paramagnetic and ferromagnetic phases in a nominally one-phase ceramics was detected in [23] in single-crystal $\mathrm{La}_{0.7} \mathrm{~Pb}_{0.2} \mathrm{MnO}_{3}$ by EPR method in the form of an integrated signal of FMR and the fine structure. The presence of the ferromagnetic phase in the $\mathrm{BiNb}_{1-x} \mathrm{Fe}_{x} \mathrm{O}_{4-\delta}$ samples can be inferred by the dependence of values of specific magnetic susceptibility of solid solutions on magnetic field strength. However, the analysis of the results of magnetic susceptibility measurements showed that, for the whole series of the solid solutions, no correlation between the susceptibility and magnetic field strength was observed. It follows from this fact that if the presence of the ferromagnetic phase in the samples is assumed, its contribution to the magnetic susceptibility value is minor.
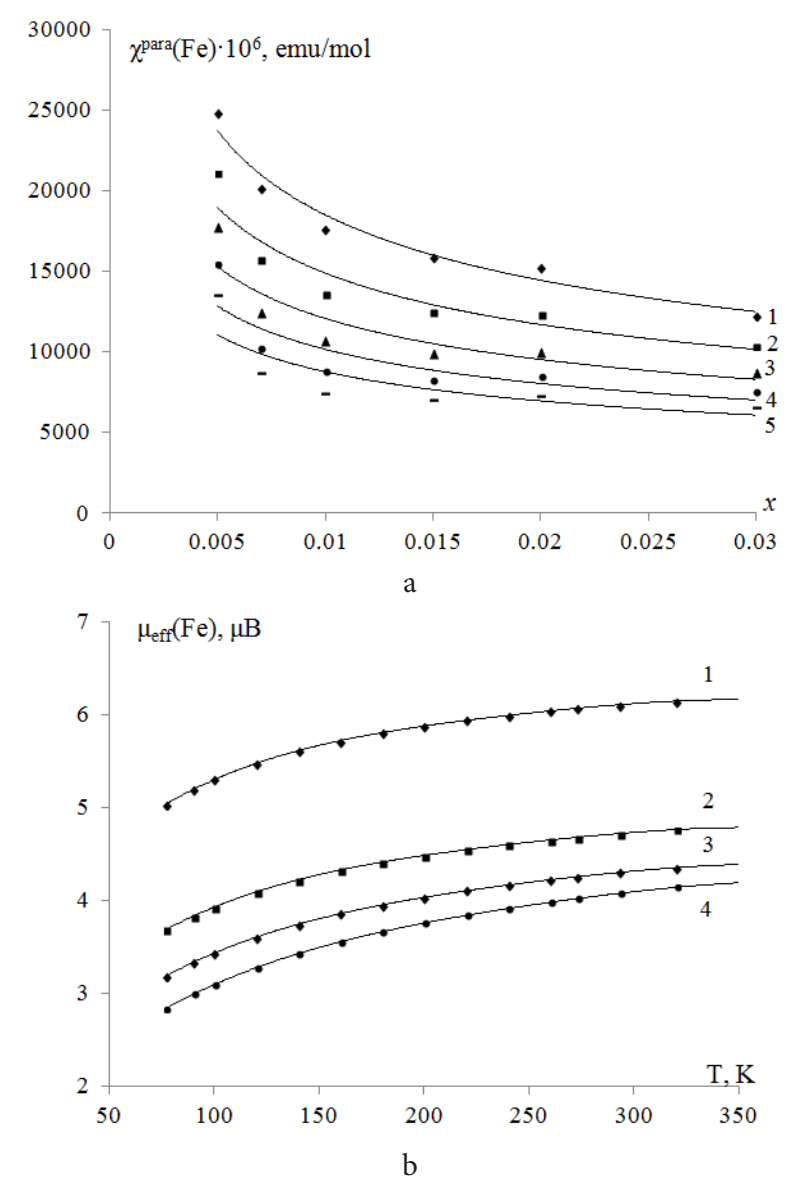

Fig. 1. Isotherms of the paramagnetic component of magnetic susceptibility of iron-containing solid solutions at $90 \mathrm{~K}(1), 140 \mathrm{~K}$ (2), $200 \mathrm{~K}(3), 260 \mathrm{~K}(4)$ and $320 \mathrm{~K}(5)$ (a); temperature dependences of the magnetic moment of iron atoms in $\mathrm{BiNb}_{1-x} \mathrm{Fe}_{x} \mathrm{O}_{4-\delta}$ at $x=0.003$ (1), 0.007 (2), 0.02 (3) and 0.03 (4) (b).

Table 1. Effective magnetic moment of iron atoms in $\mathrm{BiNb}_{1-x} \mathrm{Fe}_{x} \mathrm{O}_{4-\delta}$ at $x \rightarrow 0$.

\begin{tabular}{|c|c|c|c|c|c|}
\hline$T, \mathrm{~K}$ & 90 & 140 & 200 & 260 & 320 \\
\hline$\mu_{e f f}(\mathrm{Fe}), \mu \mathrm{B}$ & 5.84 & 6.01 & 6.16 & 6.31 & 6.43 \\
\hline
\end{tabular}


The integral intensity of the line with $g$-factor $\sim 4.3$ does not change significantly, a slight line broadening with an increase in the index $x$ from 0.015 to 0.020 is observed. The $g$-factor of the integral component of FMR, after the initial jump from 2.25 to 2.37 at the change of $x$ from 0.003 to 0.005 , monotonously decreases down to 2.16 with a further increase of the iron content. The integral intensity of this component fluctuates between 90 and 140 a.u. The increase in the intensity of the line with $g$-factor $\sim 2.2$ with the increase in the iron content in the solid solutions shows that iron atoms prefer minimally distorted positions.

Theoretical calculations of magnetic susceptibility and comparison of the data obtained with experimental ones were carried out to describe the magnetic behavior of the solid solutions. The calculations of the dependencies of $\chi^{\text {para }}(\mathrm{Fe})$ on the concentration of the solid solutions were done within the framework of the model of diluted solid solution, according to which the magnetic susceptibility is defined as a sum of contributions from single paramagnetic atoms and their exchange-bonded aggregates. The formula for calculating the paramagnetic component of magnetic susceptibility of iron atoms is given by a sum of contributions of magnetic susceptibility of monomers and dimers with antiferromagnetic and ferromagnetic types of interaction:

$$
\begin{aligned}
\chi_{\text {calc }}^{\text {para }}(\mathrm{Fe}) & =\left(1-a_{\mathrm{Fe}(\mathrm{III})}^{\text {mon }}-a_{\mathrm{Fe}(\mathrm{III})}^{\operatorname{dim}(a)}\right) \chi_{\mathrm{Fe}(\mathrm{III})-\mathrm{Fe}(\mathrm{III})}^{\operatorname{dim}(f)}+ \\
& +a_{\mathrm{Fe}(\mathrm{III})}^{\operatorname{dim}(a)} \chi_{\mathrm{Fe}(\mathrm{III}) \mathrm{Fe}(\mathrm{III})}^{\operatorname{dim}(a)}+a_{\mathrm{Fe}(\mathrm{III})}^{\text {mon }} \chi_{\mathrm{Fe}(\mathrm{III})}^{\text {mon }},
\end{aligned}
$$

where $a_{\mathrm{Fe}(I I)}^{\text {mon }}$ and $a_{\mathrm{Fe}(\text { III })}^{\text {dim(a) }}$ are ratios of monomers and antiferromagnetically-coupled dimers of iron (III), $\chi_{\mathrm{Fe}(\text { III)-Fe(III) }}^{\operatorname{dim}(a)}$ and $\chi_{\mathrm{Fe} \text { (III)-Fe(III) }}^{\text {dim-(i) }}$ are magnetic susceptibilities of $\mathrm{Fe}(\mathrm{III})-\mathrm{O}-\mathrm{Fe}(\mathrm{III})$ dimers with antiferro- and ferromagnetic types of exchange, $\chi_{\mathrm{Fe}(\mathrm{III}) \mathrm{Fe}(\mathrm{III})}^{\mathrm{dim}(\mathrm{I})}-$ magnetic susceptibility of $\mathrm{Fe}(\mathrm{III})$ monomers.

Magnetic susceptibility of dimers consisting of paramagnetic atoms was calculated using the HeisenbergDirac-van Vleck model [17], the calculation technique is given in $[24,25]$. The experimental and theoretical values of magnetic susceptibility of the solid solutions are given in Table 2. The best agreement of experimental data with the calculated ones for the solid solutions $\mathrm{BiNb}_{1-x} \mathrm{Fe}_{x} \mathrm{O}_{4-\delta}$ is obtained for the parameter of antiferromagnetic exchange $J_{d i m}=-17 \mathrm{~cm}^{-1}$ and ferromagnetic exchange $J_{\text {dim }}=45 \mathrm{~cm}^{-1}$ in dimers. The distribution of monomers and dimers of iron (III) atoms with antiferro- and ferromagnetic types of exchange is shown in Fig. 3.

An analysis of the experimental results shows that, in the case of infinite dilution, the $\mathrm{Fe}(\mathrm{III})$ atoms are in the aggregated state in the form of $\mathrm{Fe}(\mathrm{III})$-O-Fe(III) dimers with antiferro- and ferromagnetic types of exchange. The assumption on the realization of an indirect ferromagnetic exchange between $\mathrm{Fe}(\mathrm{III})$ atoms at $120^{\circ}$ angle in the crystal field of octahedral symmetry does not contradict the magnetic exchange theory [26]. In this case, the indirect ferromagnetic exchange between paramagnetic atoms occurs through the

$$
d_{x^{2}-y^{2}} \perp p_{x} \perp d_{x y}
$$

cross-exchange channels, e.g.

. Moreover, geometric distortions of the bond lengths and angles and anion vacancies formed as a result of heterovalent substitution contribute to the activation of ferromagnetic exchange. For
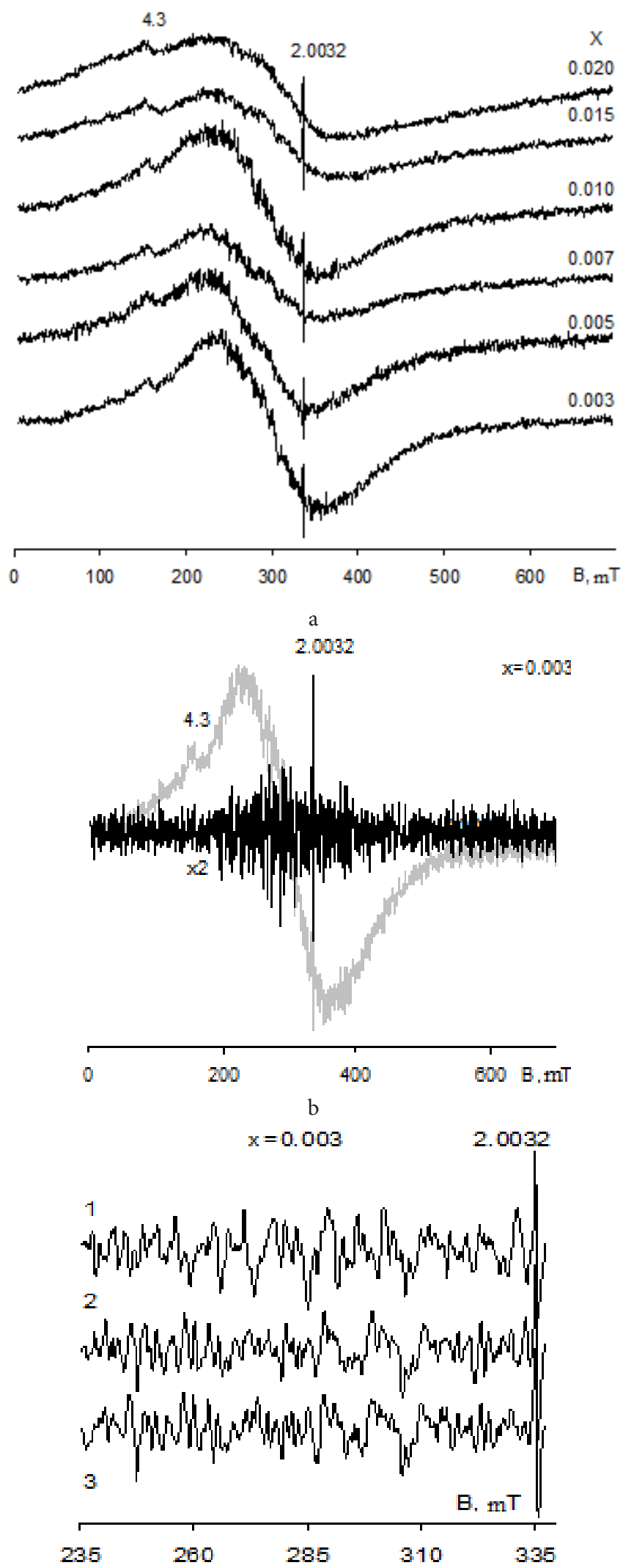

Fig. 2. EPR spectra of the solid solutions $\mathrm{BiNb}_{1-x} \mathrm{Fe}_{x} \mathrm{O}_{4-\delta}$ of orthorhombic modification (a); EPR spectrum of the $\mathrm{BiNb}_{0.997} \mathrm{Fe}_{0.003} \mathrm{O}_{4-\delta}$ sample and ferromagnetic resonance fine structure obtained by subtracting the corresponding smoothed spectrum from the EPR spectra (b); a fragment of ferromagnetic resonance fine structure before (1) and after (2) tilting the test-tube by about $5^{\circ}$ and a repeated independent recording (3) (c). 
these reasons, the antiferromagnetic type of exchange between iron (III) atoms through $d_{x^{2}-y^{2}}\left\|p_{x}\right\| d_{x^{2}-y^{2}}, d_{x^{2}-y^{2}}\left\|p_{y}\right\| d_{x^{2}-y^{2}}$ exchange channels is suppressed in highly diluted solid solutions as evidenced by low values of exchange parameters in dimers $J_{d i m}=-17 \mathrm{~cm}^{-1}$ И $J_{d i m}=45 \mathrm{~cm}^{-1}$. The possibility of the realization of the antiferromagnetic exchange between atoms of a paramagnet can be explained based on the assumption that iron (III) atoms are located in crystal fields of varying degrees of distortion. This conclusion is not in contradiction to the results of EPR studies of the solid solutions, which show that the EPR spectra contain two types of signals with $g \sim 4.3$ and $\sim 2.2$ suggesting an inequivalence of cation sites of iron atoms in the structure of solid solutions. The fraction of clusters with the ferromagnetic exchange type decreases with an increase in the solid solution concentration (Fig. 3) that can be caused by averaging of the local distortions of the structure and coarsening of the initially formed aggregates with dominantly antiferromagnetic type of exchange. Evidently, the formation of exchange-bonded aggregates in highly diluted solid solutions of bismuth orthoniobate facilitates the stabilization of the crystal structure by means of localization of aggregates close to oxygen vacancies, which reduce the degree of distortion of oxygen neighborhood of the paramagnet atoms [27].

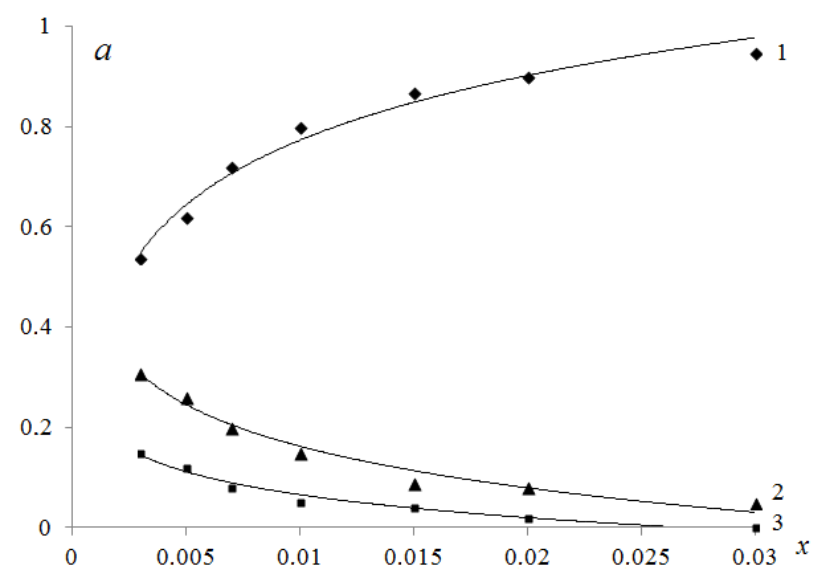

Fig. 3. Dependencies of the fractions, $a$, of dimers Fe(III)-O-Fe(III) with antiferromagnetic (1) and ferromagnetic (3) types of exchange, and monomers of $\mathrm{Fe}$ (III) (2) on the concentration of iron atoms in $\mathrm{BiNb}_{1-x} \mathrm{Fe}_{x} \mathrm{O}_{4-\delta}$.

\section{Conclusions}

The magnetic susceptibility and EPR of the solid solutions $\alpha-\mathrm{BiNb}_{1-x} \mathrm{Fe}_{x} \mathrm{O}_{4-\delta}$ of orthorhombic modification have been studied. In the EPR spectra of solid solutions, a wide band with the center at $g=2.16-2.37$ was recorded and a lowintensity signal with $g$-factor of $\sim 4.3$ was observed on its low-field wing. The two types of signals with $g \sim 4.3$ and $\sim 2.2$ observed in the EPR spectrum suggest an inequivalence of cation sites of iron atoms in the structure of solid solutions. The analysis of the results of magnetic susceptibility measurements has shown that $\mathrm{Fe}$ (III) atoms are mostly in an aggregated state forming $\mathrm{Fe}(\mathrm{III})-\mathrm{O}-\mathrm{Fe}(\mathrm{III})$ dimers with the antiferro- and ferromagnetic types of exchange. The best agreement between the experimental and calculated data is obtained for the dimer parameters of $J_{d i m}=-17 \mathrm{~cm}^{-1}$ for the antiferromagnetic type of exchange and $J_{d i m}=45 \mathrm{~cm}^{-1}$ for the ferromagnetic one.

Supplementary Material. The on-line version of this paper contains supplementary material (figures) available free of charge at the journal's Web site (www.lettersonmaterials.com).

\section{References}

1. S.S. Dunke, K.S. Suslick. J. Phys. Chem. C. 113, 10341 (2009). DOI: 10.1021/jp903163u

2. H. Kagata, T. Inoue, J. Kato, I. Kameyama. Jpn. J. Appl. Phys. 31, 3152 (1992). DOI: 10.1143/JJAP.31.3152

3. K. Sang, Y. Kyung. J. Mater. Sci.: Mater. Electron. 9, 351 (1998). DOI: 10.1023/A:1008981120219

4. Z. Wang, L. Zhang, X. Yao. Ceram. Intern. 30, 1329 (2004). DOI: 10.1016/j.ceramint.2003.12.112

5. W. Tzou, C. Yang, Y. Chen, P. Cheng. J.Eur. Ceram. Soc. 20, 991 (2000). DOI: 10.1016/S0955-2219(99)00228-9

6. C.L. Huang, M.H. Weng, C.C. Wu, C. T. Lion. Mater. Res. Bull. 36, 827 (2001). DOI: 10.1016/S0025-5408(00)00458-X

7. N. Wang, M. Zhao, Z. Yin, W. Li. Mater. Res. Bull. 39, 439 (2004). DOI: 10.1016/j.materresbull.2003.10.016

8. Y. Yang, S. Ding, X. Yao. Ceram. Intern. 30, 1335 (2004). DOI: 10.1016/j.ceramint.2003.12.111

9. Y. Yang, S. Ding. Ceram. Intern. 30, 1341 (2004).

Table 2. Calculated data on the distribution of iron atoms in solid solutions $\mathrm{BiNb}_{1-x} \mathrm{Fe}_{x} \mathrm{O}_{4-\delta}{ }^{1}$.

\begin{tabular}{|c|c|c|c|c|c|c|c|c|}
\hline \multirow{2}{*}{$x$} & \multirow{2}{*}{$a_{\mathrm{Fe}(\mathrm{III})}^{\operatorname{dim}(a)}$} & \multirow{2}{*}{$a_{\mathrm{Fe}(\mathrm{III})}^{\operatorname{dim}(f)}$} & \multirow{2}{*}{$a_{\mathrm{Fe}(\mathrm{III})}^{\text {mon }}$} & \multicolumn{5}{|c|}{$\chi_{\exp (\text { calc })} \times 10^{3}, \mathrm{emu} / \mathrm{mol}$} \\
\hline & & & & $90 \mathrm{~K}$ & $120 \mathrm{~K}$ & $180 \mathrm{~K}$ & $240 \mathrm{~K}$ & $320 \mathrm{~K}$ \\
\hline 0.003 & 0.54 & 0.15 & 0.31 & $31.9(32.3)$ & $23.9(22.7)$ & $18.4(17.2)$ & $14.9(14.0)$ & $12.6(11.9)$ \\
\hline 0.005 & 0.62 & 0.12 & 0.26 & $24.9(28.2)$ & $21.1(20.3)$ & $17.9(15.8)$ & $15.5(13.0)$ & $13.6(11.2)$ \\
\hline 0.007 & 0.72 & 0.08 & 0.20 & $20.2(22.9)$ & $15.8(17.2)$ & $12.5(13.9)$ & $10.3(11.8)$ & $8.8(10.2)$ \\
\hline 0.010 & 0.80 & 0.05 & 0.15 & $17.6(18.7)$ & $13.6(14.8)$ & $10.7(12.4)$ & $8.8(10.8)$ & $7.5(9.5)$ \\
\hline 0.015 & 0.87 & 0.04 & 0.09 & $15.9(15.6)$ & $12.5(13.1)$ & $10.0(11.4)$ & $8.3(10.1)$ & $7.08(9.1)$ \\
\hline 0.020 & 0.90 & 0.02 & 0.08 & $15.3(13.8)$ & $12.4(12.0)$ & $10.1(10.7)$ & $8.5(9.7)$ & $7.3(8.7)$ \\
\hline 0.030 & 0.95 & 0.00 & 0.05 & $12.3(11.1)$ & $10.4(10.5)$ & $8.4(9.8)$ & $7.5(9.0)$ & $6.6(8.3)$ \\
\hline
\end{tabular}

$1 \quad a_{\mathrm{Fe}(\mathrm{III})}^{\operatorname{dim}(f)}$ and $a_{\mathrm{Fe}(\mathrm{III})}^{\operatorname{dim}(a)}, a_{\mathrm{Fe}(\mathrm{III})}^{\text {mon }}$ are fractions of monomers and dimers of iron (III) atoms with ferro- and antiferromagnetic types of interactions. 
DOI: 10.1016/j.ceramint.2003.12.110

10. D. Shihua, X. Yao, Y. Yong. Ceram. Intern. 30, 1195 (2004). DOI: 10.1016/j.ceramint.2003.12.030

11. C. Yang. J. Mater. Sci. Lett. 18, 805 (1999). DOI: $10.1023 / A: 1006697318870$

12. C. Huang, M. Weng, G. Shan. J. Mater. Sci. Lett. 35, 5443 (2000). DOI: 10.1023/A:1004823711748

13. M. Weng, C. Huang. J. Mater. Sci. Lett. 19, 375 (2000). DOI: 10.1023/A:1006722301181

14. C. Cheng, S. Lo, C. Yang. Ceram. Intern. 26, 113 (2000). DOI: 10.1016/S0272-8842(99)00027-9

15. N. Wang, M. Zhao, Z. Yin. Mat. Sci. and Eng.: B. 99, 238 (2003). DOI: 10.1016/S0921-5107(02)00464-6

16. H. Lee, K. Yoon, E. Kim. Jpn. J. Appl. Phys. 42, 6168 (2003). DOI: 10.1143/JJAP.42.6168

17. V.T. Kalinnikov, Yu. V. Rakitin. Introduction to magnetochemistry. The method of static magnetic susceptibility in chemistry. Moscow, Science (1980) 302 p. (in Russian) [В. Т. Калинников, Ю.В. Ракитин. Введение в магнетохимию. Метод статической магнитной восприимчивости в химии. Москва, Наука (1980) 302 c.]

18. R. S. Roth, J. L. Waring. J. Res. Nation. Bur. Stand.-A. Phys. and Chem. 66A, 451 (1962).

19. M. A. Subramanian, J. C. Calabrese. Mat. Res. Bull. 28, 523
(1993). DOI: 10.1016/0025-5408(93)90048-I

20. L. G. Akselrud, Yu. N. Gryn, P. Yu. Zavalij, V. K. Pecharski, V.S. Fundamentski. CSD - Universal program package for single crystal and/or powder structure data treatment. Thes. Report on 12th ESM. Moscow (1989) Vol. 3, p. 155.

21. R.D. Shannon. Acta Crystallogr. A. 32, 751 (1976). DOI: $10.1107 /$ S0567739476001551

22. G.I. Malovichkov, V.G. Grachev, O.F. Schirmer, B. Faust. J. Phys.: Condens. Mater. 23, 3971 (1993). DOI: 10.1088/0953-8984/5/23/024

23. O. N. Martyanov, S. N. Trukhan, V. F. Yudanov. Appl. Magn. Reson. 33, 57 (2008). DOI: 10.1007/s00723-008-0056-1

24. N. V. Chezhina, D. A. Korolev, N. A. Zhuk et al. J. Sol. St. Chem. 247, 8 (2017). DOI: 10.1016/j.jssc.2016.12.019

25. N. A. Zhuk, N. V. Chezhina, V.A. Belyy, B.A. Makeev, L. V. Rychkova. Letters on materials. 7(4), 402 (2017). DOI: 10.22226/2410-3535-2017-4-402-406

26. D.B. Goodenough. Magnetism and the Chemical Bond. Moscow, Metallurgy (1968) 328 p. (in Russian) [Д.Б. Гуденаф. Магнетизм и химическая связь. Москва, Металлургия (1968) 328 с.]

27. N.A. Zhuk, I. V. Piir, N. V. Chezhina. Rus. J. Gen. Chem. 77, 215 (2007). (in Russian) [H. А. Жук, И. В. Пийр, Н.В. Чежина. ЖОХ. 77, 240 (2007).] DOI: $10.1134 /$ S1070363207020053 